原著 若年および壮年の境界域高血圧における

$$
\text { 血墏カテコールアミン }
$$

\begin{tabular}{ccc}
\multicolumn{4}{c}{ 九州大学医学部第二内科 } \\
河野 雄平 柊山幸志郎॰ 川崎 晃一 \\
阿部 功 尾前 照雄 \\
九州大学健康科学七ンタ一. \\
武谷 溶
\end{tabular}

\title{
PLASMA CATECHOLAMINES IN YOUNG AND OLDER JAPANESE MEN WITH BORDERLINE HYPERTENSION
}

Yuhei Kawano, MD, Koshiro Fukryama, MD, Terukazu Kawasaki, MD, Isao ABE, MD and Teruo OMAE, MD

The Second Department of Internal Medicine, Faculty of Medicine, Kyushu University Yo TAKEYA, MD

Institute of Health Science, Kyushu University

\begin{abstract}
概要 境界域高血圧における交感神経系の関与が年令によつて異なるか否かを調べるため，若 年と壮年の境界域高血王者（BHT）について血浆カテコールアミン (CA)を測定し，同年代の

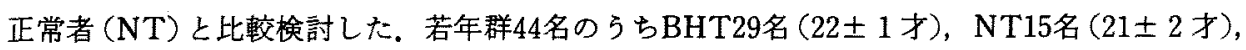

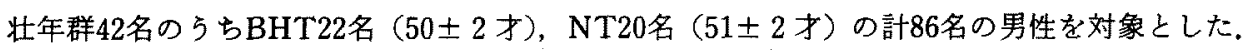

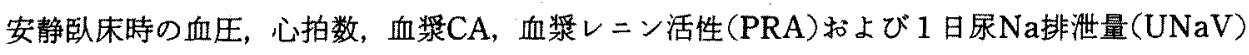
测定した。若年群のBHTはNTに比し, 心拍数, 血浆ノルアドレナリン (NA), アドレナリ ソ (Ad) の高值を示した $(\mathrm{P}<0.01)$. 壮年群のBHT, NTの間にはこれらの值に差を認めなか つた，BHTに执いては，若年群が壮年群より血采NA，Adの高值を示したが(P<0.01)，NT では両群で差認めなかつた。若年群の全例について, 血浆NA又はAdと収縮期血圧 $(r=0.660$, $\mathrm{r}=0.638)$ ，心拍数 $(\mathrm{r}=0.584, \mathrm{r}=0.611)$ との間に正相関がみられた，壮年群の全例について は，血将A，Adと血圧には相関はなく，心拍数との間にのみ弱い正相関 $(r=0.351, r=0.376$, $\mathrm{P}<0.05)$ があた。これらの成績は境界域高血圧において交感神経一副腎系の機能九進が若年 者には存在するが，壮年者には認められないことを示す。
\end{abstract}

\section{緒言}

高血圧の成因に従来より交感神経系の関与が注 目されている，血将カテコールアミン（CA) は交 感神経系の活動性のよい指標であるが12), 固定性 高血圧への移行が高率に認められるとされる境界

[昭和56年 9 月 19 日受稿]
域高血区に括いては，高值を示すとする報告3) -5) と正常であるとするもの家汭とがあり，成績の一 致をみていない，その原因の一つとして，対象者 の選択，とくに年令構成が異なることが考えられ る. 境界域高血圧における交感神経系の関与が年 令によつて異なるか否かを調べるため, 若年と壮 年の境界域高血圧者について血浆CAを測定し，同 
年代の正常者を対照に比較検討した。

\section{対象书よひ方法}

対象は86名の男性で，18～25才の若年群44名， 45 55才の壮年群42名であつた。若年群は九州大 学の学生, 壮年群は某官庁の公務員で, それぞれ 昭和54年度の春に施行された定期健康診断成績を もとに抽出された。

対象者は 1 カ月以上の期間に少なくとも 3 日 間，午後に 5 分以上の安静ののち坐位で血圧が測 定された。これら随時血圧值が少なくとす2回 150/90mmHg以上を示し, 少なくとも1回は150/ $90 \mathrm{mmHg}$ 未満を示したものを境界域高血王者 (BHT)，常に140/90mmHg未満を示したものを 正常者（NT）とした。

若年群はBHT29名 (22 \pm 1 才, mean $\pm \mathrm{SD})$ と

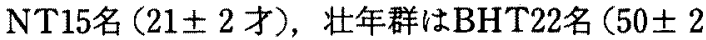
才）とNT20名（51士2才）からなつた．若年群の BHTには一部, 経静脈性腎孟造影を行ない異常な きことを認めた。

検查は午前中に行ない，当日は検査終了まで絶 食, 禁煙とした。少なくとも30分以上の臥床安静 後，血圧，心拍数の測定に引続き，血浆 $\mathrm{CA}$ ，血浆 レニン活性（PRA）のための採血を行なつた，血 圧測定は水銀血正計によつた，検查前24時間の採 尿を行ない，尿Na排泄量（UNaV）を測定した。
同時に測定したクレアチニン排泄量から，採尿が 正しく行なわれたか否かを判定した。

血浆 CA濃度はradioenzymatic method" によ り，freeのノルアドレナリン（NA)，アドレナリ ン(Ad)，ドーパミン(DA)をそれぞれ測定した。 PRAはradioimmuno assay ${ }^{10}$ により測定した。数 值はmean \pm SDで表わし, Student's t testにより 統計的分析を行なつた。

\section{結果}

若年，壮年各群の測定値を，NTとBHTそれぞ れについて一括してTable 1に示した. 臥床安静30 分後においてもBHTの血圧は，NTに比し両群之 もに取縮期圧（SBP），拡張期圧 (DBP)，平均血 圧 (MBP) のいずれあ高值であつた。しかし，血 王が正常域 (140/90 mmHg未満)に低下していた 例が若年群で13例（45\%)，壮年群で11例（50\%） に認められた，心拍数は若年群ではBHTはNTよ り有意に多く，壮年群では両者に差はなかつた。

血浆NAとAdは，若年群ではBHTがNTより有 意に高值であつたが (いずれも $\mathrm{P}<0.01)$ ，壮年群 では両者に差がなかつた（Table 1, Fig 1).

BHTの血浆NAについて各年代正常者の上限 值 (mean+2SD) を超える例は若年群の $52 \%$ ，壮 年群の $9 \%$ であつた. BHTの血奨Adは, 若年群の $62 \%$ ，壮年群の $14 \%$ で異常高値を示した。また，

Table 1. Blood pressure, heart rate, plasma catecholamines, plasma renin activity at rest and daily sodium excretion.

\begin{tabular}{|c|c|c|c|c|}
\hline \multirow[b]{2}{*}{ Variable } & \multicolumn{2}{|c|}{ Young } & \multicolumn{2}{|c|}{ Order } \\
\hline & BHT $(n=29)$ & $\operatorname{NT}(n=15)$ & BHT $(n=22)$ & NT $(n=20)$ \\
\hline $\mathrm{SBP}$ (mmHg) & $140 \pm 11 * *,+$ & $112 \pm 7$ & $130 \pm 16 * *$ & $110 \pm 10$ \\
\hline $\mathrm{DBP}$ (mmHg) & $73 \pm 12 *$ & $64 \pm 10^{H}$ & $86 \pm 6^{* *}$ & $76 \pm 8$ \\
\hline MBP (mmHg) & $95 \pm 9 * *,+$ & $80 \pm 7^{+}$ & $100 \pm 7 * *$ & $87 \pm 8$ \\
\hline HR (beats/min) & $80 \pm 7 * *, *$ & $55 \pm 8^{*}$ & $65 \pm 9$ & $64 \pm 9$ \\
\hline PNA $(\mathrm{pg} / \mathrm{ml})$ & $307 \pm 87 * *$ & $214 \pm 40$ & $215 \pm 65$ & $208 \pm 61$ \\
\hline $\operatorname{PAd}(\mathrm{pg} / \mathrm{ml})$ & $104 \pm 36 * *, \#$ & $43 \pm 13$ & $44 \pm 33$ & $46 \pm 21$ \\
\hline $\operatorname{PRA}(\mathrm{ng} / \mathrm{ml} / \mathrm{hr})$ & $2.8 \pm 2.3$ & $2.5 \pm 1.5$ & $1.9 \pm 1.8$ & $1.8 \pm 1.8$ \\
\hline $\mathrm{UNaV}$ (mEq/day) & $180 \pm 62 *$ & $229 \pm 48^{\prime \prime}$ & $137 \pm 32$ & $145 \pm 32$ \\
\hline
\end{tabular}

$\mathrm{BHT}=$ borderline hypertensives, $\mathrm{NT}=$ normal subjects, $\mathrm{SBP}=$ systolic blood pressure, $\mathrm{DBP}=$ diastolic blood pressure, $\mathrm{MBP}=$ mean blood pressure, $\mathrm{HR}=$ heart rate, $\mathrm{PNA}=$ plasma noradrenaline, $\mathrm{PAd}=$ plasma adrenaline, $\mathrm{PRA}=$ plasma renin activity, $\mathrm{UNaV}=$ urinary sodium excretion. Values are given as mean $\pm \mathrm{SD} .{ }^{*} \mathrm{P}<$ $0.05,{ }^{* *} \mathrm{P}<0.01$, when compared with $\mathrm{NT},+\mathrm{P}<0.05$, $++\mathrm{P}<0.01$, when compared with older subjects. $\S n=22$ in young $B H T, n=11$ in young $N T, n=21$ in older BHT. 


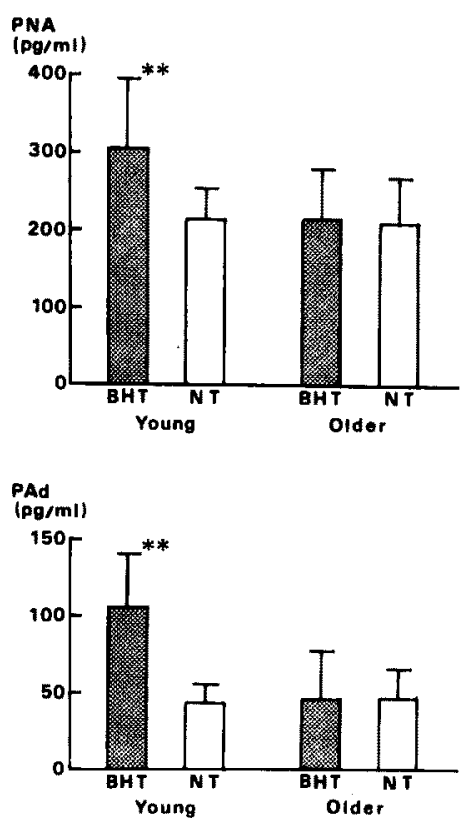

Fig 1. Resting plasma catecholamines in border. line hypertensive and normotensive subjects.

PNA : plasma noradrenaline, PAd: plasma adrenaline, BHT : borderline hypertensives, NT : normal subjects. **: $\mathrm{P}<0.01$, between BHT and NT.

若年のBHTで検査時血殴が正常であつたものは， そうでなかつたものに比し，血浆NA，Adとも低 値傾向にあつたが統計的有意差はなかつた，壮年 者ではこれらの間に差はなかつた，若年群と壮年 群を比較すると, NTの血䍝NA，Adには両群間に 差はなかつたが, BHTではNA, Adとも若年群が 壮年群より高值を示した（いずれも $P<0.01 ）$ ．血 浆DAは全例で測定感度以下であつた。

PRAは若年, 壮年群ともBHTとNTとの間に差 を認めなかつた。UNaVは若年のBHTではNTよ り低值で $(\mathrm{P}<0.05)$, 壮年群では両者に差はなか つた。 また，若年群のUNaVはBHT，NTいずれ も壮年群より大であつた。

BHTとNTを合わせた全若年者について血浆 NA，Adと血圧，心拍数との間に有意の正相関が 認められた (Table 2, Fig 2). 全壮年者について は，血浆NA，Adと血圧との間には相関はなく, 心拍数との間には正相関がみられた（Table 2, Fig 3).
Table 2. Correlation coefficient between plasma catecholamines and blood pressure or heart rate.

\begin{tabular}{rlc}
\hline & $\begin{array}{l}\text { Young } \\
n=44\end{array}$ & $\begin{array}{c}\text { Older } \\
n=42\end{array}$ \\
\hline PNA vs SBP & $0.660 *$ & -0.010 \\
DBP & $0.303 *$ & 0.070 \\
MBP & $0.537 * *$ & -0.010 \\
HR & $0.584 * *$ & $0.351 *$ \\
PAd vS SBP & $0.638 * *$ & -0.017 \\
DBP & -0.033 & -0.049 \\
MBP & $0.294 *$ & -0.050 \\
HR & $0.611 * *$ & $0.376 *$ \\
\hline * & 0.05, & $* * p<0.01$
\end{tabular}
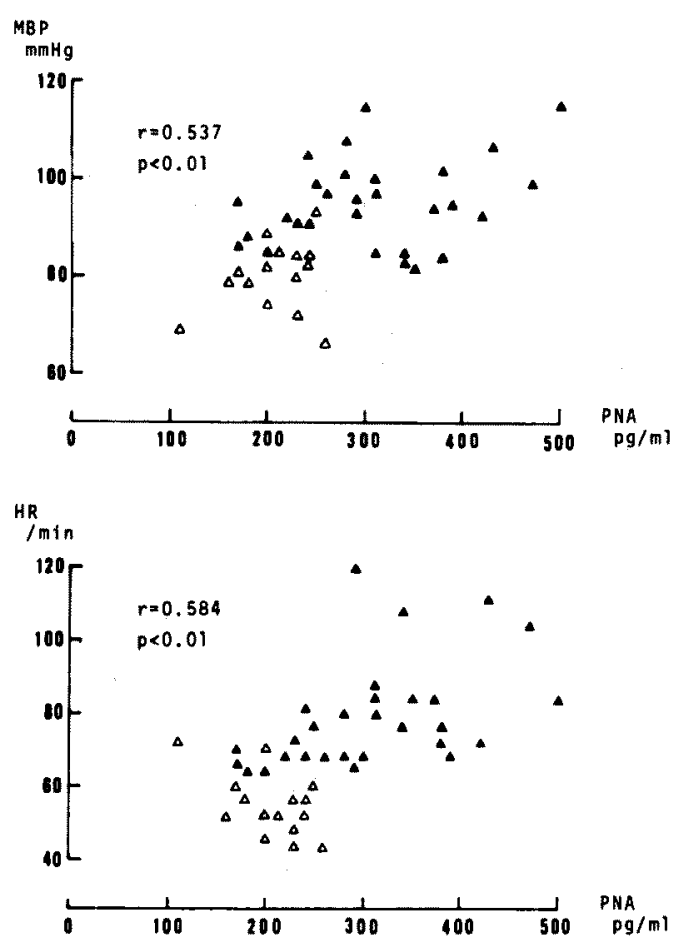

Fig 2. Correlation between plasma noradrenaline and mean blood pressure (upper panel) or heart rate (lower panel) in young males.

$(\Delta)$ indicates subjects with borderline hypertension and $(\Delta)$ normal subjects.

全若年者について，血浆NAと血浆 $\mathrm{Ad}(\mathrm{r}=$ $0.539, \mathrm{P}<0.01)$ 括よびPRA $(\mathrm{r}=0.372, \mathrm{P}<0.05)$ との間に正相関がみられた。血浆 $\mathrm{NA}$ と $\mathrm{UNaV}$ と の間には相関は認められなかつた。血浆 $\mathrm{Ad}$ 

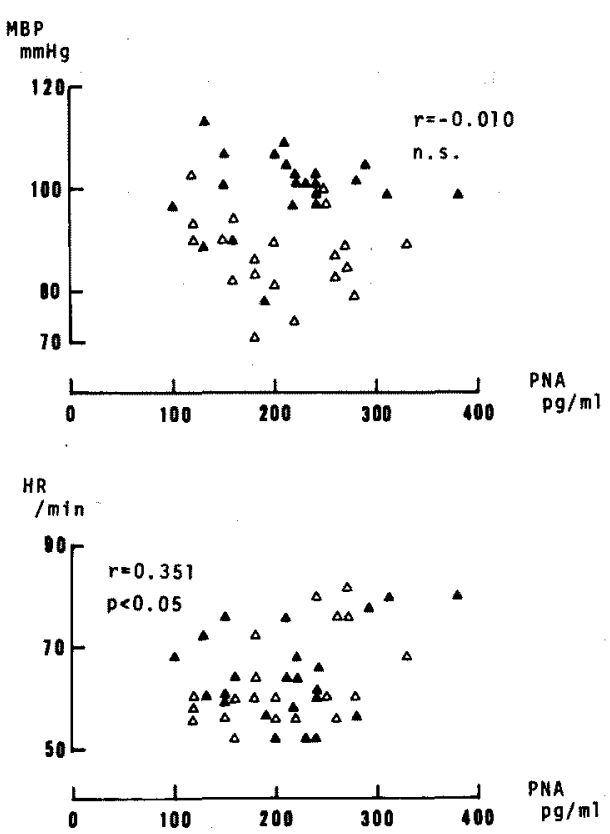

Fig 3. Correlation between plasma noradrenaline and mean blood pressure (upper panel) or heart rate (lower panel) in older males.

Symbols are same as Fig. 2.

PRAとの間には相関はなく, UNaVとの間には負 の相関 $(\mathrm{r}=-0.423, \mathrm{P}<0.01)$ がみられた. PRA とUNaVとの間には有意の相関はなかつた。

全壮年者については，血浆NAとAdおよびPRA との間に正相関 $(r=0.304, \mathrm{P}<0.05$ 和よび $\mathrm{r}=$ $0.400, \mathrm{P}<0.01)$ があり，をた血浆AdとPRAとの 間にも相関（r=0.408，P<0.01）がみられた。 $\mathrm{UNaV}$ と血浆NA，Ad，PRAとの間には相関はな かつた.

\section{考 案}

血浆CAは種々の刺激に鋭敏に反応することか ら，現在では交感神経活動性のすぐれた指標と考 えられている12)，境界域高血圧の血浆CAは高值 であるとするもの ${ }^{3(2)}$ と正常とするもの る. 境界域高血圧への交感神経系の関与は年令に 上つて異なる可能性があり，これが成績の不一致 の原因の一つであるかも知れない，血浆CA濃度は 加令の影響をらけると言われている11) 13)ので, 本 研究では，若年，および壮年について正常対照を 別々に設け，さらに若年群と壮年群の対象者をそ
れぞれ同一の社会層から選び，境界域高血王の血 浆CAを調べた。

その結果, 若年のBHTの血孚NA, Adの平均值 は正常者より高く，対象の約 $50 \%$ の例が異常高値 を示した。一方, 壮年者に拈いては血将CAはBHT とNT間に有意の差はなく，異常高値を示した例 は約10\%であつた。 また，心拍数についてもBHT はNTに比し若年群では高值であり，壮年群では 差がなかつた。

若年の境界域高血圧においては，心拍数，心拍 出量が高値，末㮐血管抵抗は正常ないし高值であ るなどの血行動態的特徵が認められている ${ }^{14)}$.こ れらは自律神経の遮断に上り正常化されることか ら, 自律神経の関与すなわち交感神経系の機能六 進と副交感神経系の抑制が重要と考えられてい る ${ }^{14)}$. 本研究子若年の境界域高血圧に扣いて交感 神経系の機能六進が関与することを支持する。一 方，壮年者においては血浆CAの增加は認められ ず，血生上昇の機序は若年者におけるそれと異な ることが考えられる。

対象者の平均年令が30 40才である境界域高血 王者の血浆CAは，高値とする報告4)5) と正常と差 がないとする報告78)がある，対象者の年代を限定 して調べた研究は少ないが, Ibsenらは40才の境界 域高血圧者の血浆NA，Adは同年令の正常血王者 と差がないと報告している6).これに対し, Miura らは15４9才を対象とし，10代から40代の各年代 に拈いて，境界域高血圧者の30－50\%に血采 NA の異常高值を認めだ!.一方彼らは，持続性高血圧 では血浆NA高值例の頻度は10代の65\%から年代 と共に減少し，40代では23\%であつたとしている。

これらの成績の間の，また我々の成績との不一 致は，年令を含めた対象者の選択によるところが 大きいであろう、我々の成績でも，BHTの血浆CA は若年者に拈いてす正常範囲にとどまる例す相当 数あり，また壮年者の少数例では高値を示してい る. 従つて，血圧が一様に高くとも，その原因は 均一でないものの集団を境界域高血圧として取り 扱つている可能性が高く，その中には交感神経系 の活動性亢進を示すむのがあり，それは若年者に 
扐いてより頻度がたかいということができる。

固定性高血圧者においても，血浆CAは高値であ るとするすのと，正常とするものとがあり，成績 は一致していない.50才未满では本態性高血王患 者の血浆NAは正常血王者より高值であり，50才 以上では差がみられないとの報告があり ${ }^{13)} ， こ の$ ことから本態性高血圧においても，ょり若年者で は交感神経系の活動性亢進が存在し，高年者とは 異なつていることが示唆される。しかし血浆CA高 值を示す境界域高血圧者が固定性高血王に進展し た場合に，血浆CAは高いレベルにとどまるか否か 未解決である。

塩分制限により血浆CAは高值になるといわれ $3^{5) 6}$. 我々のBHTにおける血采CA高值が $\mathrm{Na}$ 排泄 量，すなわち食塩摄取量の差による可能性を指摘 されるかるしれない，しかし，この成績では $\mathrm{UNaV}$ と血倸NAやPRAとの間に相関はなかつ た. 極端な塩分制限以外は食塩摄取量が血浆NA やPRAに及注す影響は少ないと言われ22，BHT での血浆CA高值は塩分掑取の差によるものとは 考光にくい.

これら境界域高血王者に扎いては寒冷などの感 覚刺激や種々の精神的刺激に対する反応性がたか く、よりつよく血王上昇反応が起こることが知ら れている，血浆CAの高値は感覚神経一交感神経反 射における視床下部あるいはより高位中权の調節 異常によつて過度の交感神経興奮がもたらされた 結果であるかもしれない，あるいは，交感神経末 端に括けるNAの再吸收の抑制や17)，血中に括け るNAの抱合化の障害 ${ }^{18}$ に起因する可能性るあ る.

一方，境界域高血圧に执いて血管の伸展性の低 下を示した成績199や，動脈のNA感受性え進を示 唆した成績》が報告されている。しかし，我々の成 樍では，若年の境界域高血圧者の外因性NAに対 する笔王反応，isoproterenolに対する心拍数増加 反応は正常者と異ならなかつた ${ }^{20)}$. 若年境界域高 血王では交感神経-副腎系の機能㐫進が存在し，そ れが血圧上昇の機序の一役を荷つていると思われ る.
壮年群の境界域高血圧において，循環血液量の 増大やレニン，アンギオテンシン系の元進を示し な確実な成績は得られていない，本成績に㨟いて も示されたよ5に，境界域高血圧の大部分の症例 は安静によつて血圧は低下するので，血王上昇に は交感神経機能の関与があると思われる。乙かし ながら壮年群の血浆CAは正常者と異ならないの でむしろ血管の構造的変化ないしは他の因子に よる血管感受性の亢進に血圧上昇の原因を求める のが妥当であるように思われる。

正常血泎者では加令と共に血浆NAは高くなる といわれる11 13)。 また，高血圧者では年令と血浆 NAに相関はなく，それは若年者の血浆NAが高值 のためとする報告がある ${ }^{13)}$. 我々の成績では，血装 NA，AdはNTに括いては若年群と壮年群で差は なく,BHTでは若年群が高值を示した，対象に老 年者を含んでいないことが，NTで年令により血 浆CAに差をみなかつたことに関係しているかる しれない。

\section{まとめ}

若年扣よび壮年のBHT（29名と22名）とそれぞ れの同年代のNT (15名と20名) を対象に, 安静臥 床時の血王, 心拍数, 血浆 CA, PRA扝よびUNaV を測定した。

1）若年群のBHTはNTに比し，血圧，心拍数， 血浆NA，Adの高值を示したが，壮年群では血圧 をのぞくこれらの值に差はなかつた，PRAは若 年, 壮年群ともにBHTとNTとの間に差はなく, $\mathrm{UNaV}$ は若年群に扎いてのみBHTがより低 値を示した。

2） BHTでは若年群が壮年群より血浆 $\mathrm{NA}, \mathrm{Ad}$ の高值を示したが，NTでは両群間に差はなかつ た.

3）若年群では血浆NAまたはAdと収縮期血 圧拉よび心拍数との間に正相関がみられたが，壮 年群に拉いては心拍数との間にのみ弱い正相関が あつた。両群ともにUNaVと血椋NAとの間に相 関が認められなかつた。

4）これらの成績は交感神経-副腎系の機能元 進が若年のBHTには存在するが, 壮年のそれには 
なく,血王上昇の機序が異なる可能性を示唆する. 文献

1) Lake $\mathrm{CR}$, et al: Use of plasma norepinephrine for evaluation of sympathetic neuronal function in man. Life Sci $18:$ 1315, 1976.

2) Robertson $D$, et al: Comparative assessment of stimuli that release neuronal and adrenomedullary catecholamines in man. Circulation $59: 637,1979$.

3) Miura Y, et al: Plasma noradrenaline levels and haemodynamics in young patients with essential hypertension. Jpn Circul J 42:609, 1978.

4) Cousineau $D$, et al: Circulating catecholamines and systolic time intervals in labile and sustained hypertension. Clin Sci Mol Med 55: $655,1980$.

5) Eide I, et al: Clinical assessment of sympathetic tone: Orthostatic blood pressure responses in borderline primary hypertension. Clin Exp Hypertension 1: 51, 1978.

6) Ibsen $\mathrm{H}$, et al: Plasma noradrenaline concentration in hypertensive and normotensive forty. year-old individuals: Relationship to plasma renin concentration. Scand J Clin Lab Invest $40: 333,1980$.

7) Weidmann $\mathrm{P}$, et al: Pathogenic and therapeutic significance of cardiovascular pressor reactivity as related to plasma catecholamines in borderline and established essential hypertension. Clin Exp Hypertension 2: 427, 1980.

8) Cuche JL, et al: Autonomic nervous system and benign essential hypertension in man. I. Usual blood pressure, catecholamines, renin and their interrelationships. Circ Res $35: 281$, 1974.

9) Peuler JD and Johnson GA: Simultaneous single isotope radioenzymatic assay of plasma norepinephrine, epinephrine and dopamine. Life Sci 21 : 625, 1977.
10). Haber E, et al: Application of a radioimmunoassay for angiotensin. I to the physiologic measurements of plasma renin activity in normal human subjects. $J$ Clin Endocrinol Metab 29 : 1349, 1969

11) Lake CR, et al: Use of plasma norepinephrine for evaluation of sympathetic neuronal function in man. Life Sci 18: 1315, 1976.

12) Weidmann $P$, et al : Age versus urinary sodium for judging renin, aldosterone, and catecholamine levels: Studies in normal subjects and patients with essential hypertension. Kidney Int $14: 619,1978$.

13) Sever PS, et al: Plasma noradrenaline in essential hypertension. Lancet $1: 1078,1977$.

14) Julius $S$ and Esler $M$ : Autonomic nervous cardiovascular regulation in borderline hypertension. Amer J Cardiol 36 : 685, 1975.

15) Luft FC, et al: Plasma and urinary norepinephrine values at extremes of sodium intake in normal man. Hypertension 1:261, 1979.

16) Wang MS, et al: Effect of sodium intake on plasma catecholamines in normal subjects. J Clin Endocrinol Metab 48: 26, 1979.

17) Esler $M$, et al: Norepinephrine kinetics in essential hypertension: Defective neuronal uptake of norepinephrine in some patients. Hypertension 3 : 149, 1981.

18) Kuchel O, et al: Essential hypertension with low conjugated catecholamines imitates pheochromocytoma. Hypertension $3: 347,1981$.

19) Takeshita A, et al: Decreased vasodilator capacity of forearm resistance vessels in borderline hypertension. Hypertension 2: 610, 1981.

20) Kawano $Y$, et al: Elevated plasma catecholamines without alteration in cardiovascular responsiveness in young men with borderline hypertension. Amer Heart $\mathrm{J}$ : in press. 